University of Louisville

ThinkIR: The University of Louisville's Institutional Repository

1942

\title{
Active carbon manufacture : iron oxides suitable for Thermit from mill scale and a resinous molding compound from citrus waste.
}

Seaton Hunter 1920-2000

University of Louisville

Follow this and additional works at: https://ir.library.louisville.edu/etd

Part of the Chemical Engineering Commons

\section{Recommended Citation}

Hunter, Seaton 1920-2000, "Active carbon manufacture : iron oxides suitable for Thermit from mill scale and a resinous molding compound from citrus waste." (1942). Electronic Theses and Dissertations. Paper 1811.

https://doi.org/10.18297/etd/1811

This Master's Thesis is brought to you for free and open access by ThinkIR: The University of Louisville's Institutional Repository. It has been accepted for inclusion in Electronic Theses and Dissertations by an authorized administrator of ThinkIR: The University of Louisville's Institutional Repository. This title appears here courtesy of the author, who has retained all other copyrights. For more information, please contact thinkir@louisville.edu. 
UNIVERSITY OF LOUISVILIE

\author{
ACTIVE: CARBON
}

IRON OXIDES SUITABLE FOR THEPMIT FROM MILU SCALE

and

A RESINOUS WOLDING COMPOUND FYOW CITRUS WASTE

\author{
A Ther18 \\ submitted to the faculty \\ of the Graduate School \\ of the University of Louisville \\ in Partial Fulfillment \\ of the Requirements \\ for the Degree of
}

MASTER OF CHEMICAL ENG INEERING

Department of Chemical Englneering

by

Seat on Hunter

1942 
ACT IVE CARBON LANUFACTURE

IRON OXIDES SUITABLE FOR THERUIT FROM MILL SCALE

and

A RESINOUS MOLDING COMPOUND FFOUI CITRUS WASTE

by

Seaton Hunter

Approved by Examining Committee:

Director 
TABLY OF CONTENTS

List of Tables $\ldots \ldots \ldots \ldots \ldots$

List of Figures $\ldots \ldots \ldots+\ldots$ Acknow ledgenent $\ldots \ldots \ldots+\ldots$ Abstract $\ldots \ldots \ldots+\ldots \ldots$. $\ldots+\ldots$ Introduction $\ldots \ldots \ldots$ The Semicommerolal Production of Activated Carbon - - - - - - 3

Historical … $\ldots \ldots \ldots$ Theoret108I $\ldots \ldots \ldots$ Experimental _. - . . . . . . . . . . . - 11 Conclusions and Recomnendations _ . . . . . . . . . 18 Literature Cited _. $\ldots \ldots \ldots \ldots$ The Manufacture of Iron Oxide for Themit from Mill Scale - - - 23

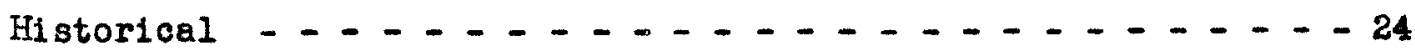

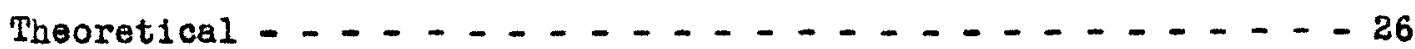

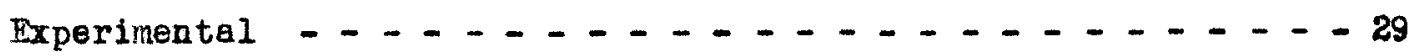

Analytical _... $\ldots \ldots \ldots$

Conclusions and Recommendations - . - . . - . . - 39

Iiterature Cited $\ldots \ldots \ldots$

A Resinous Molding Compound from Citrus Waste - . - . - . - 43

Historical $\ldots+\ldots-\ldots+\ldots$

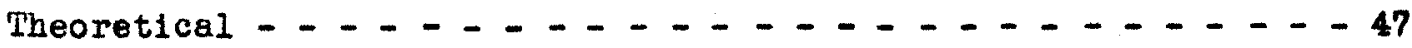

Experimental - $-\ldots \ldots-\ldots$

Conclusions - - - - $-\ldots \ldots$

Iiterature Cited - - . - . - . - . - . - 60 Vita $\ldots+\ldots \ldots+\ldots \ldots$ 
I Tabulation of Carbonization Runs $\ldots \ldots \ldots$

II Tabulation of Activation Runs _............. 17

III Production of Ferroso-Ferric Oxide $\ldots \ldots \ldots \ldots$

IV Laboratory Oxidation of Hill Scale $\ldots \ldots \ldots$

v Trial Reaction llagses $\ldots \ldots \ldots \ldots$

VI Solvent Fxtraction of Reaction Products $\ldots \ldots \ldots$

VII Reaction Hasses for Simplified Treatment - $\ldots$ 


\section{LIST OF FIGURES}

1 Diagramatic Sketch of Carbonization Kiln _ - . - . - . 13

2 Schematic Diagram of Modifled Carbonization Kiln - . - - - 31

3 Graph, Relation of Feo Content and Temperature - - - . - - 36 
ACKNOWLEDGTERENT

The Author wishes to acknowledge

the kind assistance and helpful

guldance of Doctor R. C. Ernst,

who directed this research. 
A B STRACT 
This thesis is a report on three projects; the Manufacture of Activated Carbon, Production of Iron Oxides for Thermit from M11I Scale, and Resins from Citrus Waste.

Previous experiments (6) have outlined a process for manufacturing activated carbon from citrus waste. These experiments were carried on in laboratory size apparatus. This investigation was undertaken to test the feasability of this process when applied to semicommercial operation, to determine suitable control variables, and to make improved operating cost estimetes.

The yield and activity of the carbon were determined, the amount of steam necessary was investigated, and the gas consumption during activation and carbonization was measured.

The purpose of the second investigation was to determine the conditions o: manufacture of a ferroso-ferric oxide, sultable for use in military themit mixtures, from mill scale.

The requisite temperatures and retention times were determined for a typical rod scale. The experimental work shows that the desired product could be produced continuously in a rotary kiln, with the proper adjustment of temperature.

The third investigation presents a new method for the total disposel of citrus waste. It consists of the production of a resinous molding compound from the waste through reaction with phthallic anbydride or a similar dibasic acid. The usefulness of the product is greatly enhanced by a simplification of the necessary treatments. 
Cellulose phthallates were produced both by conventional means and by dry reaction and curing. Five accelerating agents were tested and compared. The reaction products were successfully molded using temperatures around $2850 \mathrm{~T}\left(140^{\circ} \mathrm{C}\right)$ and pressures of $4500 \mathrm{lbs} . / \mathrm{sq} \cdot / \mathrm{ln}$. 
INTRODUCTION 
This investigation is divided into three parts; the Production of Activated Carbon; Oxidation of Rod Scale for Use in Thermit; and Resins from Citrus Waste.

Two sections of this investigation are part of the problem of utilization of citrus waste. Previous experiments (6) showed active carbon to be a practical product for utilization of this waste. The work reported here is the application of these deta to semi-commercial operation.

Resin formation is a new approach to the problem of the profitable disposal of citrus waste. A study was made of the reaction of a typical dibasic acid directly with the cellulose molecule.

Rod scale is a cheap source of iron oxide for incendiary mixtures, but it must be further oxidized before use. Very little data are available on the period of oxidation and the temperatures necessary; therefore experiments were made to determine tho proper length of time and the temperature necessary.

Each of thege projects is connected with the war effort since activated carbon is essential in gas masks. The process described herein provides an economical product from a domestic raw material. The resinous product offers another substitute to ease the metal shortage. The mill scale research was planned specifically to produce an iron oxide for use in incendiary mixtures. 
THE SELICONAERCIAL PRODUCTION

OF ACTIVATFD CARBON 
HISTORICA L 
The capacity of charcoal to adsorb gases hes been known for severel hundred yeers. De Saussure $(16)$ and Eunter $(8,9)$ in 1814 and 1865 respectively, made quantitative experiments on the power of wood chars to adsorb gases. Activated carbon reached its present importance only sfter the war in 1917-18.

Lack of a sufficient supply of coconut hulls, which require a minlmum of treatment to convert them into active carbon suitable for ges masks, led the army to authorize research in the field of suitable substitutes. In the course of this research, Chaney and his associates discovered certain broad principles of activation for gas and color adsorption and formulated a theory which setisfactorily explains most of the phenomena involved. (Their work $(1,2,3)$ will be discussed in a later section of this paper.) As a result of these experiments, industry was presented with a new tool which was economical and efficient and could be supplied in quantity.

Carbon was first widely used in the sugar industry. It has since been used in bleaching fats, 011s, and waxes; in adsorption and concentration of rare earth salts, alkaloids, and vitamins; in the purification of plating solutions; in the recovery of volatile solvents, particularly in the textile industry; in the purification of water of both undesirable odors and bacteria; and in many other similar but ibolated applications. Activated carbon has also been shown to bave a desirable catatytic effect on many reactions, generally deriving its effectiveness either by adsorbing the products to permit completion or adsorbing the reactants to maintain a high reactant concentration. 
This diversity of uses for activated carbon has induced several investigators to try to produce an ective cher from a carbonaceous wate material.

W. E. McFarlane (10) took out a patent on equipment for the manufacture of decolorizing carbon from bagasse. A. N. and S. N. G. Reo (13) reported a process for the manufacture of a highly active carbon from this same material. Chokkanna and Narayanan report (4) a similar process for activated carbon from rice hulls. Within the last year articles have appeared in the ifteruture on the production of carbon from agricultural waste products (5), coca beans (7), coal refuse (11), cottonseed hull bran (12), sewdust (14), and sugar factory press muds (15). 
THEOKETICAL 
It is readily apparent from numerous experiments that there are different kinds or forms of carbon. While ordinary charcoal has a tendency to adsorb gases, the amount is negligible in comparison to thet adsorbed by a good activated carbon. The question naturally arises, what is the difference in these carbons and how may active carbon be prepared? The general principles of activation and a satiafactory theory of activation were first stated by Chaney $(1,2,3)$ and h1s co-workers in 1919. His theory depends upon two assumptions which are the result of experiment:

(1) That elementary carbon (other than dianond and graphite) exists in two modifications "active" and "inactive", or alpha and beta.

(2) That all "primary" amorphous carbon consists essentially of a stabilized complex of hydrocarbons adsorbed on a base of "active" or alpha carbon. According to his theory, the active modiflcation is rormed whenever carbon is deposited by the decomposition of carbon bearing materials at relatively low temperatures, in general below 932 or $1012^{\circ} \mathrm{F}\left(500\right.$ to $\left.600^{\circ} \mathrm{C}\right)$. The inactive modification results from a similar decomposition of carbon bearing materials at higher temperatures.

The active form is readily attacked by oxidizing agents; the inactive form resists oxidation, resembling graphite in this respect. Thus the two forms are characteristically distinct and easily differentiated, both by their properties and conditions of formation. 
It has been postulated that a primary char produced at low temperatures, consists of the active modification of carbon in a complex with hydrocarbons. It is known by experiment that such a char is not active. If the hypothesis is true, the only thing necessary to produce the expected activity of alpha carbon is to remore the hydrocarbons. Throe methods of removal are possible; (1) dist1lletion, (2) extraction with solvents, and (3) selective chemical action. Chaney $(1,2,3)$ found that distillation was completely impractical. Hydrocarbons, which ordinarily distill at low temperatures, are so held by the adsorptive power of the carbon that they remain after hours of heatine at $1650^{\circ} \mathrm{F}\left(900^{\circ} \mathrm{C}\right)$. Solvent extraction offers some experimental promise, but to the uuthor's knowledge, has never been put into comnercial production.

Selective chemical action, specifically oxidation, is practical. When primary chars are hoated in a stream of steam or air, the hydrocarbons are selectively oxidized leaving a relatively pure alpha carbon. There is some contamination by inactive carbon deposited at the high temperatures of 1650 to $1740^{\circ} \mathrm{F}\left(900\right.$ to $\left.950^{\circ} \mathrm{C}\right)$, which have been found necessary, and there is a loss of alpha carbon, but the product is active, and the yleld is sufficiently high to justify the process.

Ir support of the hypothesia that primary chars are complexes of alpha carbor and hydrocarbons, this may be said: (1) it is the logical result of the unique adsorptive power active carbon is assumed to have: (2) it accounts for the non-adsorptive properties of 
ordinary chars; (3) it accounts for the fact, experimentally determinod, that carbon deposited at low temperature from co and sinilar nonhydrocarbon compounds is extremely active and requires no activation; (4) it is in harmony with all known methods of activation and directly suggests the zast effective method of all, namely, selective cherical attack by controlled oxidation.

The exact nature of the two carbon forms is inderinite. $X$-ray studies $(1,2,3)$ of the inactive form indicate a definite crystalIine pattern characteristio of all graphites. The active form is also shown to be crystalline but has a different $x$-ray pattern.

This lack of exact knowledge of the nature of the two const1tuents does not impeir the usefulness of the theory. It still serves as an excellent means of retionalizing experimental results and tends to stimulate the consideration of now methods of attack. 
11.

EXPERI TNTAL 
Equipment:

The experimental work of this research was carried out on a pilot plant scale, using an externally fired, cylindrical kiln. The k1ln proper was made of a seven foot length of $18^{\prime \prime}$ cast iron p1pe. A shart was supported alone the axis of the pipe by two babbitted bearligs. To this shaft were attached $3^{\text {" }}$ rakes spaced at $9^{\prime \prime}$ intervals along the shaft. The shaft was motor driven at the rate of 20 R.P.W. The k1ln was enclosed in a fire-brick housing, leaving a spece between the tube and the wall for the flue gases to pass. Heat was supplied by a fíason Premix gas burner, which fired at the bottom of the shell at the exit end of the kiln. Thus the hottest gases were run counter current to the materlal to be carbonized or activated. A schematic drawing of this appratue is shown in Fig. 1 . An exhaust fan drew the stack gases around the tube and out of the room. The tube itself was arranged with a double foed valvo. It discharged into a metal hopper which was bolted to the kiln during a run. Thus all extraneous gases were shut out. Proviaion was nade at the exit end of the tube for the admission of steam. An exhaust pipe was provided at the feed end for waste steam and any other gaseous materials produced during the reaction.

Staam from the central heating supply was not available during these experiments. Therefore a small boller was necessary as auxillary equipment. A cast aluminum tank was used, having the top drilled for gauge and ateam outlet. Ihis boller was also gas heated and supplied saturated steam. Steam consumption was measured by weigking the tank before and after a run. 


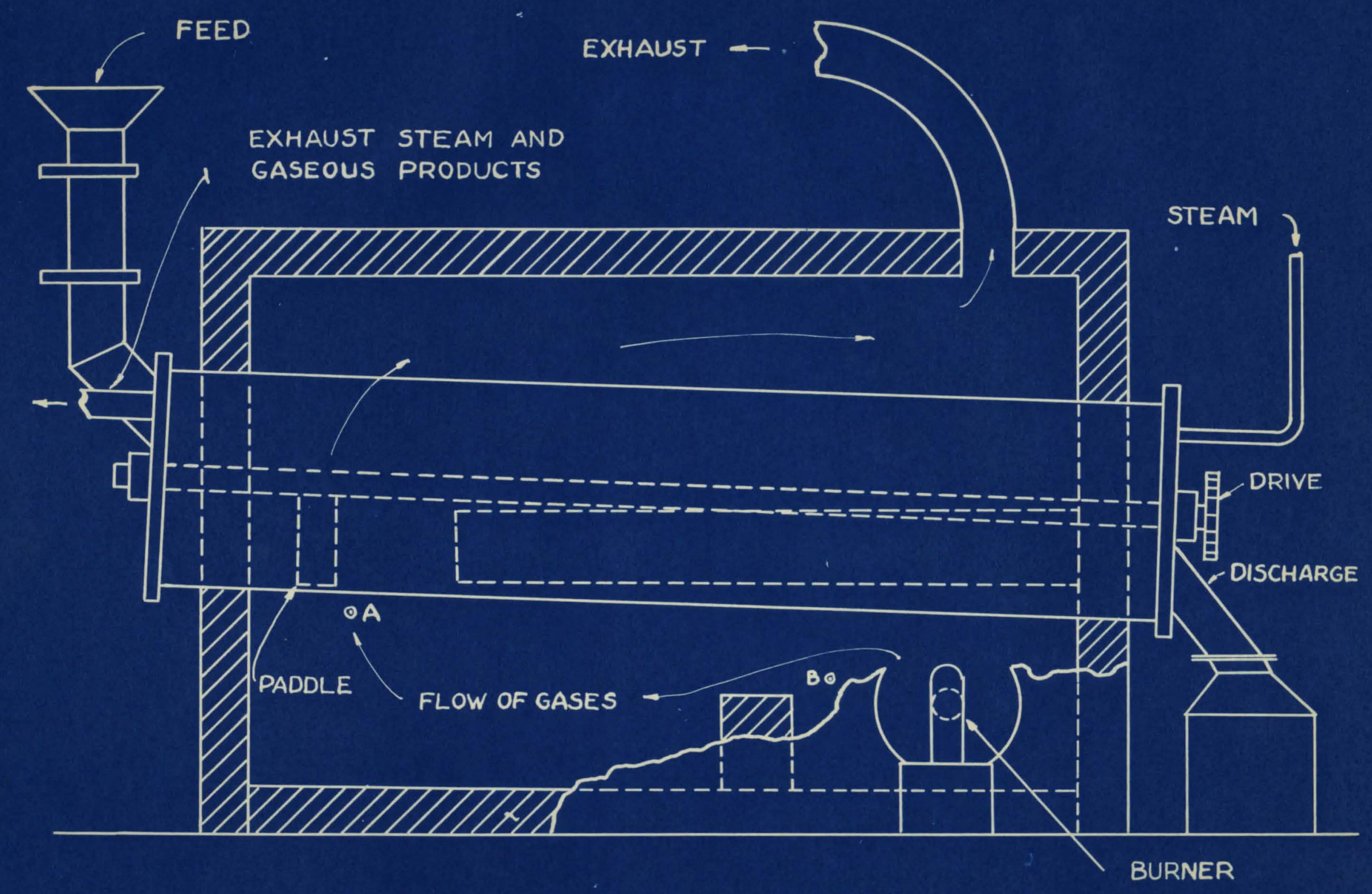

FIGURE ।

DIAGRAMATIC SKETCH OF CARBONIZATION KILN 
The temperature of the burner gases was measured at the feed end of the shell after the gases had passed over one length of the tube. Chromel-alumel thermocouples were uswa li conjunction with a Leods and Northrup potentiometer.

Procedure and Results:

The first step in the production of activated carbon from citrus waste is carbonization at low temperature. Any temperature below $930^{\circ} \mathrm{F}\left(500^{\circ} \mathrm{C}\right)$ which gives complete carbonization is satisfactory.

In the experiments reported here, the raw material was dried c1trus waste, packed by the Citro-Canners Association, Dade Park, Floride. Ten carbonization runs were made with temperatures varying from 480 to $570^{\circ} \mathrm{F}$ and feed rates from 24 to 180 hr. Yields ranged from $23 \%$ to $45 \%$. All pertinent deta on these runs are tabulated in Table I.

The primary carbon produced from c1trus waste must be given additional treatment to activate it. This is the next step in the production of an active char. Activation, according to the theory of Chaney as ated earlier in this paper, consists of removing the screenling hydrocarbons from the active carbon. This is done by dif ferential oxidation using steam at temperatures ranging as high as 1740 F (950 C). Laboratory experiments (6) have shown that a ratio of steam to carbon of 1 to 1 is desirable.

The char was activated in the kiln already described. Nine runs were made with a variation in measured temperature from 930 to $1250^{\circ} \mathrm{F}$. The ratio of steam to carbon ranged from .17 to .78 pounds 
TABLE I

TABULATION OF CARBONIZATION RUNS

\begin{tabular}{|c|c|c|c|c|c|c|}
\hline $\begin{array}{l}\text { Run } \\
\text { Nuraber }\end{array}$ & $\begin{array}{c}\text { Average } \\
\text { Temperature } \\
\mathrm{O}_{\mathrm{F}}\end{array}$ & $\begin{array}{c}\text { Average } \\
\text { Temperature } \\
\text { o }_{\mathrm{C}}\end{array}$ & $\begin{array}{r}\text { Weight } \\
\text { Charged } \\
\text { Pound } 8\end{array}$ & $\begin{array}{c}\text { Rate or } \\
\text { Feed }\end{array}$ & $\begin{array}{r}\text { Woight } \\
\text { Product }\end{array}$ & $\notin$ Yield \\
\hline C-5 & 482 & 250 & 51.1 & 24.IH/hr. & 15.75 & 30.9 \\
\hline$c-6$ & 572 & 300 & 25.3 & $50.5 \mathrm{ft} / \mathrm{hr}$ & 9.4 & 37.1 \\
\hline$c-7$ & 491 & 255 & 61.0 & $48.8 \mathrm{H} / \mathrm{hr}$ & 21.0 & 34.4 \\
\hline$C-8(1)$ & 491 & 255 & 48 & $38.4 \# / \mathrm{hr}$ & 11.0 & 23.0 \\
\hline$C-9$ & 492 & 258 & 72 & $41.14 / h r$. & 23.4 & 32.4 \\
\hline$c-10$ & 482 & 250 & 60 & $40.0 \# / \mathrm{hr}$ & 21.4 & 35.9 \\
\hline$c-11$ & 482 & 250 & 60 & 48.0 薀/ hr. & 15.5 & 25.8 \\
\hline$c-12$ & 482 & 250 & 60 & $48.01 / \mathrm{hr}$ & 18.1 & 30.2 \\
\hline$c-13$ & 491 & 255 & 96 & $35.0 \# / \mathrm{hr}$ & 43.3 & 45.0 \\
\hline$C-14$ (2) & 491 & 255 & 60 & $180.0 \mathrm{H} / \mathrm{hr}$ & $\longrightarrow$ & $\longrightarrow$ \\
\hline
\end{tabular}

Notes: Gas consumption averaged $79.4 \mathrm{cu}$. t./. hr.

(1) Incompletely carbonized; equilibrium had not been reached.

(2) Slight evidence of incomplete carbonization. 
of steam per pound of carbon. Activities, expressed as percent of the activity of ivuchar C, varied from 13.2 to 63.2 . Data from these runs are tabulated in Table II.

Measurements:

It will be noticed that the maximum temperature measured during carbonization was $570^{\circ} \mathrm{F}$ and during activation was $1250^{\circ} \mathrm{F}$; whereas temperatures as high as $930^{\circ} \mathrm{F}$ and $1740^{\circ} \mathrm{F}$ are recomnended respectively. These are temperatures measured at point $A$ on the diagramatic sketoh of the apparatus in Fig. 1. The gases have already traversed one side of the kiln, and there has been a large temperature drop. It was attempted to measure the temperature at point B, Fig. I, but flame impingement gave such erratic results that no correlation was possible. There was no means avallable to measure the maximum temperatures on the interior of the tube. The temperatures used were estimated to give approximately the desired maximums on the interior of the kiln, namely $930^{\circ} \mathrm{F}$ during carbonization and $1740^{\circ} \mathrm{F}$ during activation. The temperature attained in activation was probably lower than this.

Analysis:

After activation, the carbon was sampled, boiled in $10 \% \mathrm{HCl}$ for 30 minutes, filtered, washed thorougily, and dried overnight at $212^{\circ} \mathrm{F}$. It was then compared with Nuchar $\mathrm{C}$, using a standard loaine adsorption test. The activity of the sample was reported as a percentage of the adsorption of Nucher C. That is

$$
\frac{\text { gms. iodine adsorbed by sample }}{\text { gms. Lodine adso rbed by Nuchar } c}=\$ \text { Activity }
$$

A complete procedure for this test may be found in The Modern 
PABLE II

TABULATION OF ACTIVATION RUNS

\begin{tabular}{|c|c|c|c|c|c|c|c|}
\hline $\begin{array}{l}\text { Run } \\
\text { Number }\end{array}$ & $\begin{array}{c}\text { Average } \\
\text { Tempereture } \\
\text { OT }\end{array}$ & $\begin{array}{c}\text { Average } \\
\text { Temperature } \\
\text { O }_{\mathrm{C}}\end{array}$ & $\begin{array}{l}\text { Welght } \\
\text { Carbon }\end{array}$ & $\begin{array}{l}\text { Weight } \\
\text { Product }\end{array}$ & $\begin{array}{c}\text { \% Yield } \\
\text { (based on } \\
\text { Cerbon } \\
\text { charged) }\end{array}$ & $\begin{array}{l}\text { Steam } \\
\text { lbs./1b. } \\
\text { of Carbon } \\
\text { Charged }\end{array}$ & $\begin{array}{c}\text { Activity } \\
\text { \% of Nuchar C }\end{array}$ \\
\hline$A-5$ & 932 & 500 & 15.75 & 10.25 & 65 & - & 31.7 \\
\hline$A-7$ & 1203 & 595 & 19.75 & - & $\longrightarrow$ & - & 13.8 \\
\hline$A=8$ & 1130 & 610 & 22.0 & 7.7 & 35.0 & - & 21.6 \\
\hline A-9 & 1192 & 650 & 17.3 & 10.6 & 60.9 & .17 & 33.5 \\
\hline$A-10$ & 1148 & 620 & 33.6 & 21.9 & 65.4 & .51 & 32.9 \\
\hline A-11 & 1211 & 655 & 33.6 & 21.9 & 65.4 & .51 & 32.9 \\
\hline$A-12$ & 1192 & 650 & 15.2 & 3.9 & 26.0 & .49 & 63.2 \\
\hline$A-13$ & 1247 & 675 & 9.75 & traco & - & .44 & 57.6 \\
\hline A-14 & 1238 & 670 & 10.25 & 3.0 & 24.0 & .78 & 61.6 \\
\hline
\end{tabular}

Note: Gas consumption averaged $234 \mathrm{cu}$. ft./hr. 
CONCLUSIONS AND RECOMLENDATIONS 
The data of Tables I and II Indicate an overall yield of active carbon of approximately 20\%. It is shown that the activity attainable is definitely related to the steam to carbon ratio. The activity of the carbon produced, messured by iodine adsorption, approaches that of Nuchar $\mathrm{C}$ as the steam, carbon retio approaches one pound per pound. All these conclusions are based on an actiration temperature of 1650 to $1740^{\circ} \mathrm{F}$.

In a commercial installation it would be much simpler to measure the flue gases at some point along the kiln, than to place temperature measuring instruments inside the kiln. The experience of the author ind cates that this is a completely satisfactory method of control. The temperature should be measured after the gases heve passed over one length of the kiln to minimize minor fluctuations in flame temperature. This form of measurement is possible because the kiln operates under equilibrium conditions. The capacity of the experimental kiln used was found to be greater than 100 pounds of citrus waste charged per hour. This would be a safe figure to use for the design of larger kilns. The kiln required 90 cublc feet of gas per hour during carbonization and 240 cuble feet per hour during activation. The gas consumption was essentially independent of the rate of feed for the experimental kiln. On a larger unit where heat losses are a smaller percentage of the gas requirements, the gas consumption could be expected to vary with the rate of feed.

Regarding the design of commercial kilns of similar type, the ges consumed goes almost entirely into heat losses. Most of the 
heat 108s, particularly during activation, is in the stack gas. By combining the boiler, which produces steam for the sctivation, wi th both the activation and carbonization kilns, the thermel efficiency could be greatly improved. The gases would first make steam, then heat the activation kiln, next the carbonization $k i l n$, and finally could be used in a preheater for the boller water. In a well designed kiln of larger capacity, the gas consumption should not exceed 250 cubic feet per 100 pound of waste for all operations. 
(1) Chaney, N. K.; Ray, Arthur B; St. John, Ancel, Trans. A. I. Ch. E., 15, 309, 1923.

(2) Chaney, N. K.; Lamb, A. B.; W1lson, R. E., J. Ind. Eng. Chem., 11, 420-467, 1919.

(3) Chaney, N. K., Trans. An. Electrochem. Soc., 36, 91, 1919.

(4) Chokkanna, N. G.; Narayanan, B. T., Cur. Se1., 6, 617, 1938.

(5) Davis, Raymond G., U. S. Patent 2,245,579, June, 1941.

(6) Fletcher, Delbert V., Master of Chen. Eng. Thesis, University of Lou1sville, 1941.

(7) Hertzo\&, E. S.; Broderick, S. J., U. S. Bureau of Mines, Report of Investigations, 3548, 27pp., 1941.

(8) Hunter, Ph11. Hag., 25, 364, 1863.

(9) Ibid., 29, 116, 1865.

(10) McFarlane, W. E. Jr., U. S. Patent 2,148,827, February, 1939.

(11) Musser, D. M.; Engel, H. C., Ind. Eng. Chem., 32, 1636-8, 1940.

(12) Nugey, R. B., Gordiar, 46, 1084, 1940.

(13) Rao, S. N. G.; Rao, A. N., Cur. Sc1., 6, 616, 1938.

(14) Rao, A. H.; Jain, N. S., Proc. Sugar Tech. Assoc. India, pt. 1, 293-302, 1940.

(15) Samaniego, Ramon; de Leon, Antonio, Phillipine Ag., $29,275-95,1940$.

(16) de Saussure, G11b. Ann., 47, 113, 1814.

(17) The Wodern Purifier, p. 7, Industrial Chemical Sales, Division of West Virginia Pulk and Paper Co., 1941. 
THE IANUFACTURE OF IRON OXIDE FOR THERUIT FROU MLI SCALE 
HISTORICAL 
Thermite is a name given to any gysten capable of a rapid, highly exotbermic reaction, which does not yield gaseous products. Thermites are usually composed of a reactive metal and a metal oxide. The high temperatures available from such reactions have been used in weldine, recovery of metals from their ores, and incendiary bombs. In recent years the name thermite has been associated most frequently vith a mixture of iron oxide and aluminum.

The use of aluminum or aluminum screp in thermite mixtures is mentioned as early as 1916 (1), but these earlier combinations were scarcely similer to the moder mixtures. For example, a patent was isgued in 1920 (7) for "a solid ignitable mixture" to be made by "heating a finely divided motallic sulfide or sulfur and a metallic material as aluminum or zine to a temperature of $190^{\circ}-200^{\circ} \mathrm{C}$ and, if desired, combining with ferroso-ferric oxides".

The basic incendiary mixture used by the United States Army is Thermit. It consists of (5) 3.2 parts of ferroso-ferric orido to 1 part of granular aluminum. This investigation is concerned with the conditions necessary for the production of this ferroso-ferric oxide from mill scale. The iron oxide specified has the following aralysis: (6)

$$
\begin{array}{lc}
\text { Total iron } & 69 \% \text { min. } \\
\text { Ferrous iron } & 16.5 \% \text { (Approx. 20\% FeO) } \\
\text { Free iron } & .5 \% \text { max. }
\end{array}
$$

The theoretical temperature of reaction of an aluminum-iron oxide mixture such as Thermit is $5790^{\circ} \mathrm{F}\left(3200^{\circ} \mathrm{C}\right)$. Wartenberg and hehner (8) give the actual temperature attained as 4808 to $4170^{\circ} \mathrm{F}\left(2250\right.$ to $\left.2300^{\circ} \mathrm{C}\right)$. 
THEORFTICAL 
Ferric oxide is the end product of the oxidation of iron, its lower oxides, and many of itg salts. Mellor (3) gives several references on the preparation of ferric oxide. Among them, Sabatur and Senderens (3) observed that iron reduced by hydrogen at a low temperature, when heated to $390^{\circ} \mathrm{F}\left(200^{\circ} \mathrm{C}\right)$, burned to ferric oxide. Fedoteef and Petrenko (3) reported that the end product of the oxidation of 1 ron at 1830 to $2010^{\circ} \mathrm{F}\left(1000\right.$ to $1100^{\circ} \mathrm{C}$ ) is ferric oxide, with intermediate products being ferrous and ferrosic oxides. In this sane reference, numerous chemlcal methods of obtaining the oxide are rentioned, but these are unsultable for anything but laboratory preparation.

C. C. Furnas (4) reported that at a temperature around $1690^{\circ} \mathrm{F}$ $\left(920^{\circ} \mathrm{C}\right)$ ferric oxide tends to flow like water, although there is no liquid present. He attributed tbis phenomenon to an evolution of gas or an accumulation of static charges.

F. T. Walden (4) reported the following values for the dissociation pressures of forric oxide in mm of mercury.

$\begin{array}{rrrrrrrr}{ }^{\circ} \mathrm{F} & 2010 & 2100 & 2190 & 2280 & 2370 & 2460 & 2550 \\ { }^{\circ} \mathrm{C} & 1100 & 1150 & 1200 & 1250 & 1300 & 1350 & 1400 \\ \mathrm{p} & 5.0 & 7.0 & 9.0 & 20.0 & 59.5 & 166.0 & 454\end{array}$

This would ind cate complete conversion to ferrosic oxide at approximately $2460^{\circ} \mathrm{F}$ according to the oquation

$$
6 \mathrm{Fe}_{2} \mathrm{O}_{3} \rightarrow 4 \mathrm{Fe}_{3} \mathrm{O}_{4}+\mathrm{O}_{2}
$$

with no appreciable decrease in rate of formation due to dissociation below $2000^{\circ} \mathrm{F}$. Since the maximum temperatures used in this investigation were below $1800^{\circ} \mathrm{F}$, dissocittion certainly does not enter into consideration. 
Bullens (2) gives a curve relating the rate of scale formation on steel with temperature. At $1300^{\circ} \mathrm{F}$ the oxide penetration is .001 inch per hour and at $1600^{\circ} \mathrm{F} .004$ inch per hour. Of course this is not directly applicable to mill scale since scaling is an oxidation of steel, and mill scale is already on oxide. Nevertheless the data do show the sharp effect of moderate variations in temperature, which might be expected in the further oxidation of mill scale. 
EX P H I I EN TAL 
The experimental portion of this investigation is divided into two distinct parts. First, several muns were made, preparing iron oxide fram mill scale in a semicomercial kiln. Second, data were obtained which relate the composition of the mill scale with the tempersture for varying heating times.

The first runs were made in the tubular kiln described in the preceding section of this report. For part of these experiments the kiln was modified as shown schomatically in Fig. 2. Two raw materials were used. One was a scale from the American Rolling illis and the other was from the Bethlehem Steel Conpany. The former was fine and flaky while the latter was coarser, tended to granularity, and had some large plates in it. The finer, thinner material was much easier to oxidize. The material was 52 percent Feo.

Where secondary air was used, it was supplied by a small centrifugal blower. Thts blower was found to give an air velocity In the cross section of the kiln of $.6 \mathrm{ft.} / \mathrm{sec}$.

The data for these runs are presented in Table III. Rans 2 through 6 were made with the kiln indirect fired as it was used in carbon activation. The heat transfer in these cases was too slow to raise the bulk of the material to a high enough temperature. It is interesting to note that in run 9 , the fines had a better analysis than the bulk material, although the fineg were probably blown out of the kiln within ten minutes of the start, and the bulk material was heated for seven hours. All subsequent runs were made without any excess alr except that carried in by the venturi action of the Plame. 


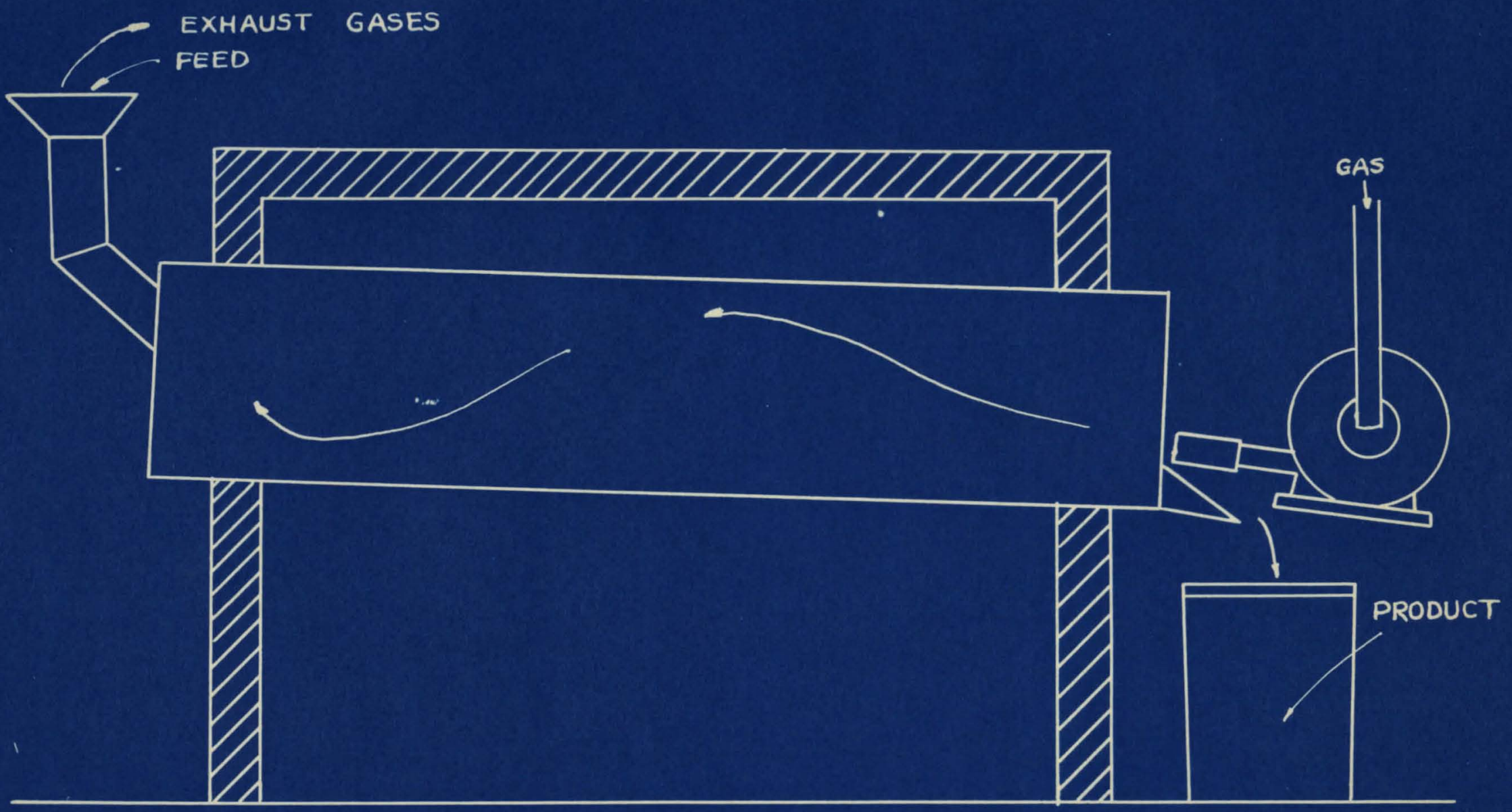

FIGURE 2

SCHEMATIC DIAGRAM OF CARBONIZATION

KILN MODIFIED FOR DIRECT FIRING 
PRODUCTION OF FTROSO-FERRIC OXIUE

\begin{tabular}{|c|c|c|c|c|c|}
\hline $\begin{array}{l}\text { Puun } \\
\text { Number }\end{array}$ & Time & $\% \mathrm{FeO}$ & $\begin{array}{l}\% \mathrm{Fe} \\
(\text { total })\end{array}$ & $\begin{array}{l}\text { Mes sured } \\
\text { Temperature } \\
\text { OF }\end{array}$ & Notes \\
\hline 2 & $\begin{array}{l}\text { 意 } \mathrm{hr} \text {. } \\
1 \mathrm{hr} .\end{array}$ & $\begin{array}{l}44.6 \\
42.0\end{array}$ & $\begin{array}{l}74.2 \\
74.2\end{array}$ & $\begin{array}{c}1050 \\
(\text { point A) }\end{array}$ & $\begin{array}{l}\text { Indirect fired; secondary air } \\
\text { unknown. }\end{array}$ \\
\hline 3 & $\begin{array}{l}\frac{1}{2} \mathrm{hr} . \\
1 \mathrm{hr} .\end{array}$ & $\begin{array}{l}56.8 \\
55.6\end{array}$ & $\begin{array}{l}74.7 \\
74.7\end{array}$ & $\begin{array}{c}960 \\
(\text { point A) }\end{array}$ & $\begin{array}{l}\text { Indirect fired; } 377 \text { t secondary } \\
\text { air/hr. }\end{array}$ \\
\hline 4 & $\begin{array}{l}1 \mathrm{hr} . \\
2 \mathrm{hrs} . \\
3 \mathrm{hrs} .\end{array}$ & $\begin{array}{l}55.7 \\
53.0 \\
47.8\end{array}$ & $\begin{array}{l}73.0 \\
74.7 \\
74.1\end{array}$ & $($ point A) & $\begin{array}{l}\text { Indirect fired; } 377 \# \text { secondary } \\
\text { air } / \mathrm{hr} \text {. }\end{array}$ \\
\hline 5 & $\begin{array}{l}3 \text { hrs. } \\
4 \text { hrs. } \\
5 \text { hrs. }\end{array}$ & $\begin{array}{l}47.5 \\
45.3 \\
40.9\end{array}$ & & $\begin{array}{l}1202 \\
(\text { point } A)\end{array}$ & $\begin{array}{l}\text { Indirect fired; } 377 \# \text { secondary } \\
\text { eir } / \mathrm{hr} \text {. }\end{array}$ \\
\hline 6 & $\begin{array}{ll}1 & \text { hr. } \\
2 & \text { hrs. } \\
3 & \text { hrs. }\end{array}$ & $\overline{28.0}$ & & $\begin{array}{c}1274 \\
(\text { point A) }\end{array}$ & Very thin scale. \\
\hline 7 & $\begin{array}{l}1 \text { hr. } \\
2 \text { hrs. } \\
3 \text { hrs. }\end{array}$ & $\begin{array}{l}47.1 \\
30.8 \\
29.9\end{array}$ & & $\begin{array}{l}\text { Temperature } \\
\text { not measu red. }\end{array}$ & $\begin{array}{l}\text { Kiln direct fired as shown } \\
\text { in Fig. } 2 .\end{array}$ \\
\hline 8 & $\begin{array}{ll}2 & \text { hrs. } \\
3 & \text { hrs. } \\
4 & \text { hrs. } \\
5 & \text { hrs. } \\
6 & \text { hrs. } \\
7 & \text { hrs. } \\
8 & \text { hrs. }\end{array}$ & $\begin{array}{l}46.3 \\
42.0 \\
40.6 \\
26.2 \\
27.9 \\
29.2 \\
22.3\end{array}$ & & & $\begin{array}{l}\text { Kiln direct fired. } \\
\text { Paddles added to rakes } \\
\text { to improve showering. }\end{array}$ \\
\hline
\end{tabular}


TABLE III - (Continued)

PRODUCTION OF FERROSO-FURRIC OXIDE

Run

Number

9

91

10

12

12 quarterod sample

13
Time

$1.5 \mathrm{hrs}$.

$4.0 \mathrm{hrs}$.

$7.0 \mathrm{hrs}$.

2 hrs.

$2 \mathrm{hrs}$.

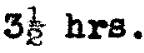

3竞 hrs.

$5 \mathrm{hrs}$.
21.8

13.0

\# FeO

34.4

29.2

34.7

20.2

35.3

15.9

25.7
Notes

Raw material was the product of funs 7 and 8 combined. Pedales were slowed from 20 R.P.M. to

7 R.P.M. No secondary air.

Fines collected around stack during Run 9.

Minimum gas and air to reduce gas velocity in kiln and hold Ines. 120 cu. It. $\mathrm{O}_{2}$ added at 1 cu. rt./bilin.

Fine, thin scale used. Direct firine with no excess air. Thermocouple indicated $1850^{\circ} \mathrm{F}$ in exit material.

Total iron $73.2 \%$

Metallic iron . $14 \%$

Dust chamber was added to kiln to retain fines. 
The mill scale never stayed in the kiln continuously for the long periods of time mentioned in some of the runs. It was recycled frequently so that over two-thirds of it was always in the kiln. The times recorded are overall times.

The best product obtained was from Run 12 . This meets the specifications in every respect. The material was probably maintained at a higher temperature in this run than in any other, but the most important factor was the fineness and uniformity of the mill scale used. It was sufficiently thin to oxidize readily and not fine enough to blow amay.

To obtain the data relating temperature, ferrous oxide content, and duration of heating, 50 gram samples of the scale were treated in a laboratory muffle furnace. Temperature was controlled with a rheostat and measured with a chromel-alumel thermocouple. The sample was spread on a steel plate and the temperature measured directly over the sample. There was no forced air supply. Where agitation was used, it was done by hand using a wire rake inserted throush a peep hole in the furnace door.

The data secured are presented in Table IV. A graphisal interpretation is given in $\mathrm{H}^{\prime} \mathrm{B}$. 3, which enables one to predict the analysis of a similar mill scale heated for certain periods of time at any temperature within the range of the experiment. 
TABLE IV

LABORATORY OXIDATION OF MILL SCALE

$\begin{gathered}\text { Run } \\ \text { Number }\end{gathered}$
$1 \mathrm{~A}$
$1 \mathrm{~B}$
$2 \mathrm{~A}$
$2 \mathrm{~B}$
$3 \mathrm{~A}$
$3 \mathrm{~B}$
$4 \mathrm{~A}$
$4 \mathrm{~B}$
5
6

\begin{tabular}{ll} 
Time & \multicolumn{2}{c}{ Temperature } \\
$15 \mathrm{~min}$. & 1305 \\
$30 \mathrm{~min}$. & 1312 \\
$15 \mathrm{~min}$. & 1435 \\
$30 \mathrm{~min}$. & 1435 \\
$15 \mathrm{~min}$. & 1600 \\
$30 \mathrm{~min}$. & 1597 \\
$15 \mathrm{~min}$. & 1708 \\
$30 \mathrm{~min}$. & 1708 \\
$15 \mathrm{~min}$. & 1670 \\
$30 \mathrm{~min}$. & 1560 \\
\hline
\end{tabular}

$\%$ FeO
49.4
42.6
45.7
37.1
26.0
21.6
24.5
14.7
27.5
25.5
7.7
26.2
27.3
$15.7(1)$
17.5

Note (1) Agitated every five minutes. 


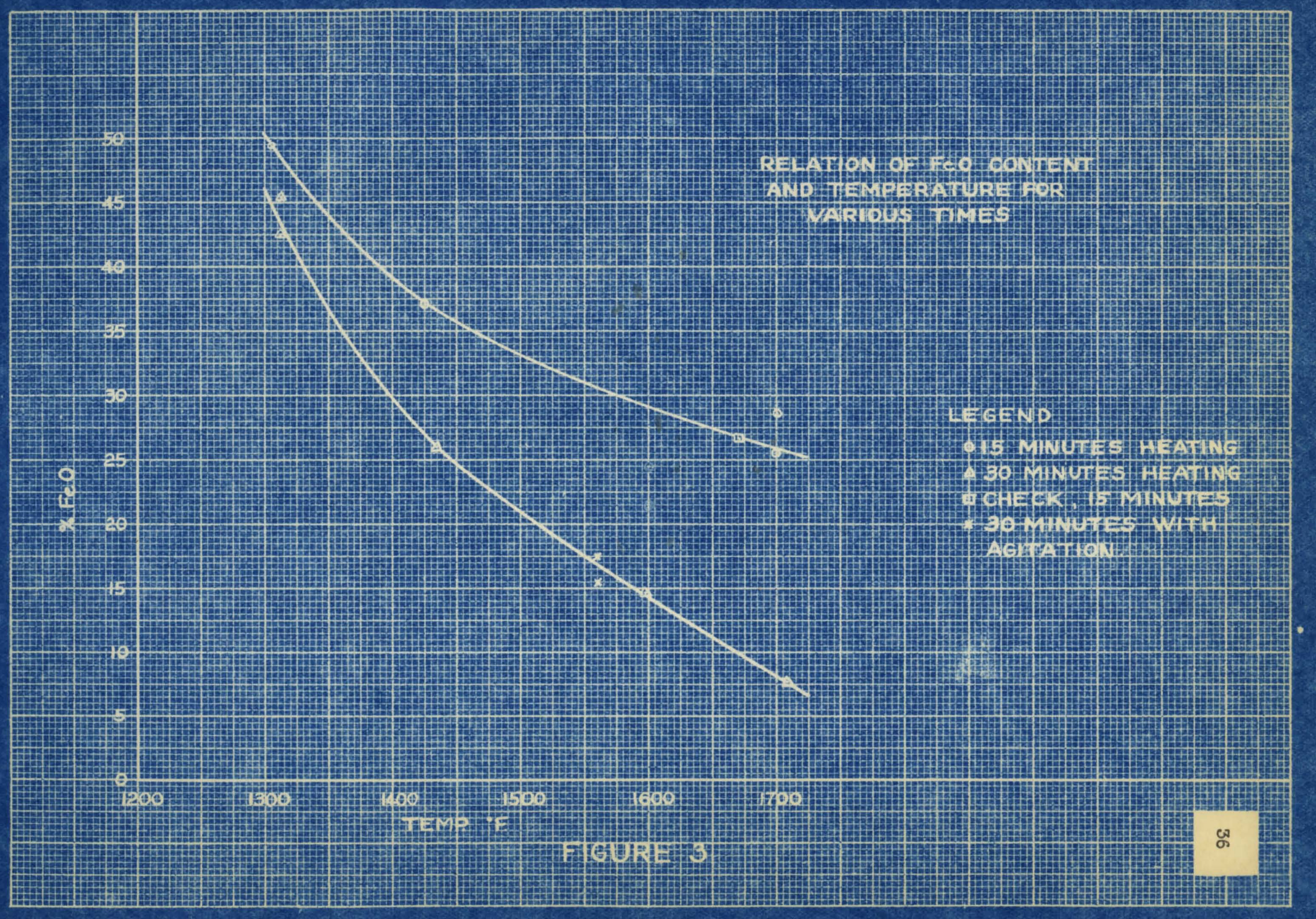


A N A I T I C A L 
Perrous Iron:

A .6-.8 gms sample was welghed into a small erlenreyer flask, $10 \mathrm{ml} \mathrm{HCl}$ added, and the air displaced with $\mathrm{CO}_{2}$. The sample was digested for one hour just below the bolling polnt. It was then rinsed into a casserole with $300 \mathrm{ml}$ of weter and $25 \mathrm{ml}$ of preventive solution*. It was titrated with $1 \mathrm{~N} \mathrm{KGinO}_{4}$.

Total Iron:

A. $2-.3 \mathrm{gm}$ sample was weighed into a mall erlenmeyer flask, $10 \mathrm{ml} \mathrm{HCl}$ added, and the samplo digested just below the boillng point until dissolved. Stannous chloride solution was added dropwise throughout the algestion just auficient to keep the ferric ion coloration out. When digestion was complete, $10 \mathrm{ml}$ of mercuric chloride solution was added and allowed to stand for two minutes. The mixture was then rinsed into a casserole, preventive solution added, and titrated as above.

Free Iron:

A I m. ample was weighed into a $100 \mathrm{ml}$ erlenmeyer. Three grams of mercuric chloride and $50 \mathrm{ml}$ of bolling water were added. The flask was transferred to a steam bath for 10 minutes. Ihe liquid was filtered into $350 \mathrm{ml}$ of water containing $25 \mathrm{ml}$ preventing solution and titrated with .1 $\mathrm{N} \mathrm{\textrm {BanO } _ { 4 }}$.

$\left(^{*}\right)$ - Prevontive Solution

$\begin{array}{lll}67 \mathrm{gms} & \mathrm{MnSO}_{4} & 4 \mathrm{H}_{2} \mathrm{O} \\ 138 \mathrm{mI} & \mathrm{H}_{3} \mathrm{PO}_{4} & \mathrm{sp} \cdot 8 \cdot 1.7 \\ 130 \mathrm{ml} & \mathrm{H}_{2} \mathrm{SO}_{4} & \mathrm{sp} \cdot 8 \cdot 1.82 \\ \mathrm{H}_{2} \circ \mathrm{to} 1 \text { 11ter } & & \end{array}$


CONCLUSIONS AND RECOWAEND TIONS 
The data presented in Fig. 3 show graphically the effect of increasing the temperature of roasting of mill scale from 1300 to $1600^{\circ}$. Oxidation for one-half hour at $1300^{\circ} \mathrm{F}$ only reduces the $\mathrm{F} \theta 0$ content to $45 \%$, whereas one-half hour at $1600^{\circ} \mathrm{F}$ produces an oxide safely within the government specifications. A temperature of $1600^{\circ} \mathrm{F}$ and a retention time of one-half hour are within the feasible limits of rotary kiln design.

Certain features must be borne in inind in the design of such equipment. A relatively short portion of the kiln can be maintained above $1500^{\circ} \mathrm{F}$, and below that temperature little reaction takes place. Therefore there is no need of a long kiln. The retention time must be adjusted so that the scale remains above $1500^{\circ} \mathrm{F}$ for one-half hour. This means the actual retention time nust be longer than one-half hour, the exact time depending on how much of the k1ln is above $1500^{\circ} \mathrm{F}$. Thernal efficiency may be improved by using the stack gases under waste heat bollers, to supply power for crushing and screening operations that are necessary in the process. The final decision on the use of such heat economizers must be based on the cost of such additional investment and the saving in fuel. 
LITERATURE CITED 
(1) British Patent 126,021, October, 1916.

(2) Bullens, Steel and Its Heat Treatment, Vol. 1, 297, John W1ley Sons, 1938.

(a) Mellor, A Comprehensive Treatige on Inorganic and Theoretical Chemistry, Vol. 13, 776, Longmans and Co., 1925.

(4) ib1d, Vol. 13, 792.

(5) U. S. Army Specifieation 196-131-37 (Restricted)

(6) U. S. Army Specification 4-503-206A.

(7) U. S. Patent 1,313,709, October, 1920.

(3) Wartenburg; Wehner, Z. Elektrochem, 42, 293-8, 1936. 
THE PRFPARATION OF A RESINOUS

MOIDTNG COMPOUND

from

CITRUS WASTE 
HIS IOR I C A L 
Previous research in the fleld of cellulose plastics has followed the principle of chemical preparation of a compound, followed by purification and molding. Such materials are often mixed with wood flour or other filler before molding, in order to improve the strength. Good examples are cellulose acetate and ethyl cellulose. It would be much cheaper to form the moldins powder by mixing the ingredients dry and bringing about the reaction by curing, or even during molding. If the reaction were incomplete, the material would be ready filled. That is the alm of this research.

The compound which it was desired to produce was an ester of cellulose with phthallic acid or any similar dibasic acid. Phthallates were chosen because phthallic anhydride is widely available at a reasonable price. A study of the preparation of the pure ester is instructive even though a much aimpler procedure is desired.

Several investigatorg have studied the reaction of phthallic anhydride, but their interest has been either a mere study of the compound or the preparation of an airplane dope to replace cellulose acetate.

Levey (I) considered the possibility of usine cellulose phthallate as a dope in 1920. He prepared a compound of the formula $\mathrm{C}_{8} \mathrm{H}_{4} \mathrm{O}_{3}-$ $\mathrm{C}_{6} \mathrm{H}_{10} \mathrm{O}_{5} \cdot 4 \mathrm{H}_{2} \mathrm{O}$, by heatine phthallic anhydride and hydrocellulose for 24 hours at $158^{\circ} \mathrm{F}\left(70^{\circ} \mathrm{C}\right)$ in the presence of a condensing agent such as $\mathrm{ZnCl}_{2}$. The reaction was carried out in diethyl phthallate or glacial acetic acid. The product was not prictical as a dope.

Dreyfus (3) mentioned cellulose phthellate prepared by the action of phthallic acid on cellulose in the presence of chloracetic anhydride. 
Worden (4) referred to a method of preparsition given by Sw1ss Patent 142, 173. Twenty parts of phthallic anhydride wore added to a inture of 8 parts cellulose in 160 parts of a mixture of benzene pyridintum chloride and fyridine at $212^{\circ} \mathrm{T}$. The mass was stirred for 1 hour at $212-220^{\circ} \mathrm{F}$. The material obtained was poured into $1000 \mathrm{cc}$ of water containing 50 pyridine. The powder that firat precipitated became completely dissolved. Cellulose phthallate was precipitated by acidifyine, It was then filtered, washed, dried, and extracted with acetone. It was soluble in weak bases and aqueous fyridine, and insoluble in most organic solvents as acetone, alcohol, and benzene.

Marsh (2) mentions the preparation of several cellulose esters of similar nature to cellulose phthallate. Amone them are tho benzoate, naphthenate, cinnamate, and phenylacetate.

None of these previous experimenters have suggested their product as a plastic material. They have been interested in the ester mainly from its theoretical aspect as a new compound of cellulose. The present investigution is concerned with the development of this compound into a ready filled plastic made by the partiel reaction of citma waste. 
T HEORETICA L 
The chief chenical characteristic of cellulose is the hyaroxy groups that it contains. The cellulose molecule is made up of building units of this structurel formula.

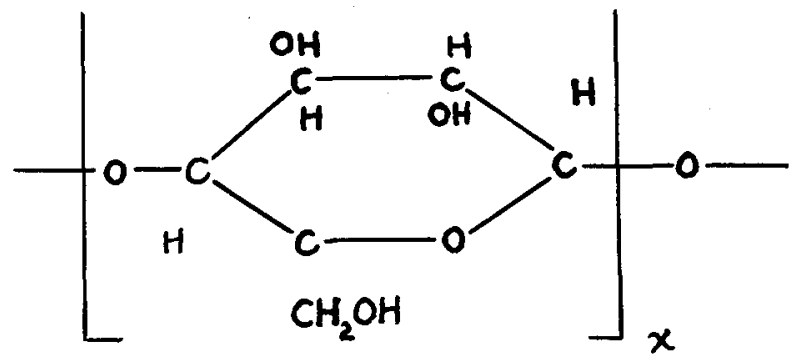

Each unit of this chain contains two secondary alcohol groups and one primary alcohol group. There is an obvious similarity to glycerol in that each unit of the cellulose contains three hydroxy groups as does the glycerol molecule. Glycerol reacts with phthallic anhydride or other dibasic acids to form the improtant group of resins known as alkyds.<smiles>OCC(O)CO</smiles><smiles>CCO</smiles>
$+2$<smiles>OCCO</smiles>

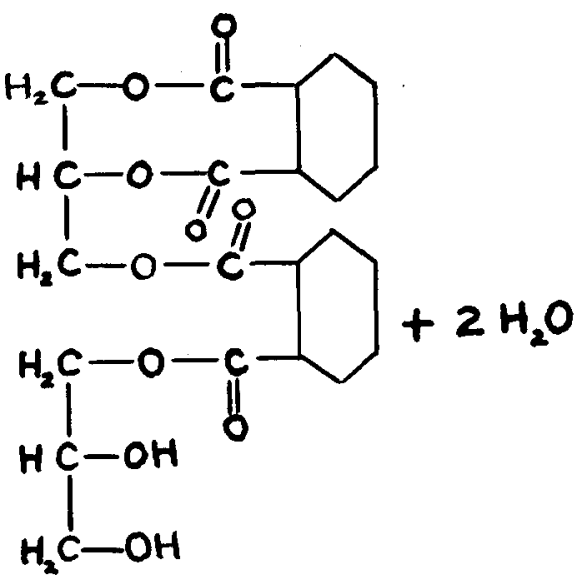

It is apparent from the formula that a chain results from the tying together of two or more glycerol molecules. Furthermore the phthallic anhydride may act as a bridge to produce three dimensional polymers of great complexity. This groupin $n_{\mathcal{G}}$ into larger molecules is characteristic of resins. 
The similarity of cellulose and glycerol has already been pointed out. Cellulose can undergo a very similar reaction with dibasic acids. From previous experience with alkyds, a resinous compound would be the logical result. The cellulose derivative might be expected to heve even nore desirable characteristics than the famillar alkyds, since cellulose is already a large chain molecule. The cross linkages produced by the phthullic anhydride would produce three dimensionel polymers. Experience with other polyraerization reactions would cause one to expect high insolubility fran such a polymer and the findings of Levey (I) confirm this.

This esterificction reaction of the cellulose units is cheracteristic, because of the hydroxy groups present. If such a reaction can be made to take place directly, without elaborate reaction procedures, the result should be a cheap, ready-filled plastic material. 
EXPRIA ENAL 
The most useful information in the literature on this inrestigation, comes frow the chemistry of the alkyds snd from the preparation of pure cellulose phthallate. These two sources have been used as guides in planning the work.

The plan of attack on the problem was to start with the laboratory preparations for cellulose phthallate and diverge from there. The first experiments were made by substituting citrus waste for cellulose in a procedure very similar to that outlined in varsh (2). Ihe phthallic anhydride and citrus waste, together with any promoters or catalyats, were suspended in glacial acet1c acid and heated at 158 to $175^{\circ} \mathrm{F}\left(70\right.$ to $\left.80^{\circ} \mathrm{C}\right)$. The time varied from 20 lours to one week. Then the acetic acid was filtered off, the product washed thoroughly, and dried at $158^{\circ} \mathrm{F}$. The resulting powdor was molded as described later. In order to prevent possible confusion arisine from the reaction of portions of the citrus weste other than the cellulose, other experiments were made using pure al pha cellulose and hydrocellulose. The hydrocellulose was prepared from alpha collulose by suaking in $1 \%$ $\mathrm{HCl}$ and drying overnight at $158^{\circ} \mathrm{F}$.

The products of these reactions were molded in an Adolph Beuler metallographic mounting press. This is an hydraulic press equipped with an electrically heated mold. It produces a pellet one inch in diameter. The thickness is dependent on the amount of powder used. The mold was filled and heated to $275^{\circ} \mathrm{F}\left(135^{\circ} \mathrm{C}\right)$ under a pressure of $3500 \mathrm{lbs} / \mathrm{sq}$. in. This took from five to ten minutes depending on whether the mold was already hot. Then the pressure was ralsed to $4500 \mathrm{lbs} . / 8 \mathrm{~g} \cdot \mathrm{In}$. and main- 
TABLE V

TRIAL REACIION LIASSPS

Run

Number

3

4

\section{Composition}

48 gms. Phthall1c Anhydride

32 n Citrus Wasto

$4 " \quad \mathrm{ZnCl}_{2}$

48 gms. Phthollic Anhydride

32 " Citrus Waste

$4 \quad \mathrm{ZnCl}_{2}$

$24 \mathrm{gms}$. Hydrocellulose

48 " Phthallic Anhydride

$4 " \mathrm{ZnCl}_{2}$

24 gins. Alphe Cellulose

48 " Phthallic Anhydride
Time

Tempereture

176

80

$20 \mathrm{hrs}$.

7 days

176

80

24 hrs.

176

80

7 days

176

80

\section{erature}

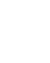

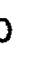

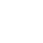


TABLE V - (Continued)

TRIAL REACTION MASSES

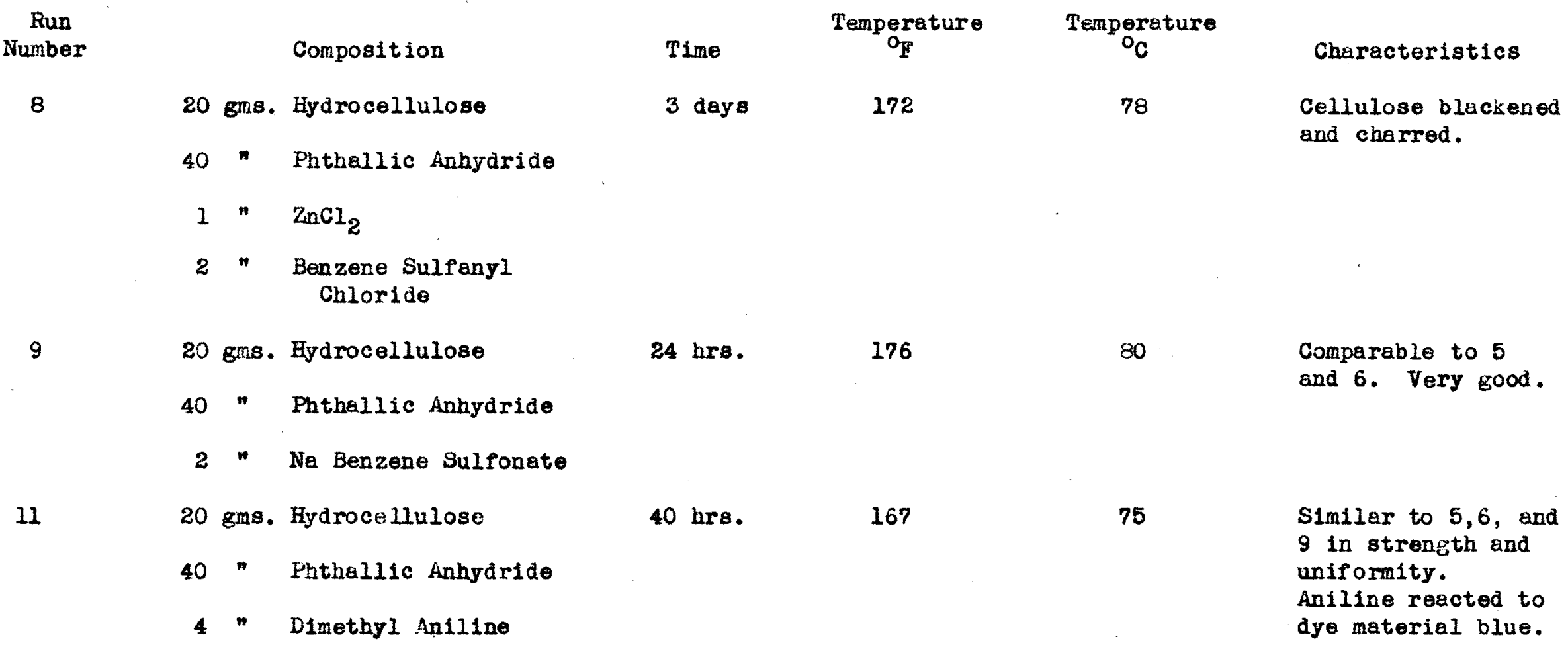

Note: All reaction masses were suspended in glecial acetic acid. 
tained until the temperature fell below $212^{\circ} \mathrm{F}\left(100^{\circ} \mathrm{C}\right)$. This took from fifteen to twenty minutes.

The data for these runs are tabulated in Pable v. The characteristics of each pellet are recorded together with 1ts composition and history.

The products of runs $3,4,5,6,10$, and 16 were studied by extraction to determine the extent of resinification. The composition and treatment of runs 10 and 16 are given in Table VII. Ten gram amples were subjected to successive extractions vith acetone and $7 \%$ NaOH. The acetone should take out the unreacted phthallic anhydride. The dilute alkall should dissolve the cellulose phthallate. The residue would then be unreacted cellulose. The results of these extractions are assembled in Table VI. They show that approximately $40 \%$ of the material is reacted.

The f1rst attempt at a resin formed without pre-treatment was simply a mechanical mixture of ground citmis waste and phthallic anhydride. The reaction was supposed to take place in the mold. These samples were very heterogeneous. Specks of phthallic anhydride were scattered through the final pellets. This mixture was molded on the machine previously described, but a maximum temperature of $257^{\circ} \mathrm{F}$ $\left(225^{\circ} \mathrm{C}\right)$ was used to prevent excessive sublination of phthallic anhydride. Eellets molded at $257^{\circ}$ F were harder and darker than others molded at $212^{\circ} \mathrm{F}$.

Next a similar mixture was ground together in a mortar. It was molded, holding at a top temperature of $248^{\circ}$ F for fifteen minutes. 
TABLE VI

SOLVENT EXTRACTION OH REACTION PRODUCTS

\begin{tabular}{|c|c|c|c|c|c|c|}
\hline & Run 3 & Run 4 & Pan 5 & Fun 6 & Run 10 & Fun 16 \\
\hline $\begin{array}{l}\text { Acetone } \\
\text { Extractible } \%\end{array}$ & 30.2 & 28.3 & 20.4 & 21.0 & 23 & 36 \\
\hline $\begin{array}{l}\text { NaOH }\left(70^{\circ}\right) \\
\text { Extractible }\end{array}$ & $\begin{array}{l}\text { Swelled a badiy } \\
\text { that filtration } \\
\text { was impossible }\end{array}$ & 43.1 & 33.0 & 36.8 & 29 & 23 \\
\hline Residue & & 28.6 & 46.6 & 42.2 & 52 & 41 \\
\hline \& Reacted & & $* 60.0$ & 41.5 & 46.6 & $* 35.8$ & *38.0 \\
\hline
\end{tabular}

* Note: NaOH extractible has probably been incressed by materialo soluble in dilute NaOh in original waste. 
Run

Number

1

5 gms. Phthallic Anhydride

20 "Citrus Weste

2

5 gno. Phthallic Anhydriao

20

Citrus Wasto

$720 \mathrm{gms}$. Citrus Waste 20 (Approx) Phthallic
Anhydride

1020 gms. (Approx) Phthallic Anhydride Sodium Benzene Sulfonate

16

150 gms. Citrus Waste

80 " Phthallic Anhydride

$15 \cap \mathrm{AlCl}_{3}$

$17 \quad 115$ " Citrus Waste

75 "Phthallic Anhydride

10 "Na Benzene Sulfonate
Type of Reaction

Time

$\underset{\mathrm{O}_{F}}{\text { Temperature }}$

Physical mixture.

\section{Ground together}

1n mortar.

Impregnated with anhydride solution, dri ed, cured and extracted.

As above.

Ground in ball mill 12 hours and cured not extracted.

Ground in ball mill 3 hours and cured.

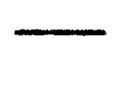

$18 \mathrm{hrs}$.

212

\section{Characteristies}

Very heterogeneous.

Higher moldine temperatures give harder, darker pellets.

Held at $120 \mathrm{C}$ for $15 \mathrm{~min}$. in mold. An ingrovement over 1 but still heterogeneous.

Molded into a moderately homogeneous pellet.

6 hrs. $\quad 212$

3uch better than 7 .

24 hrs. 176

Smooth, uniform pellet. Slightly brittie.

24 hrs. $\quad 176$

Good pellet. 
There was a marked improvement, but the product was st111 heterogeneous. The difficulty in these experiments was in a lack of intimate contact between the phthallic anhydride and citrus waste and in too short a reaction time. The next step employed was to dissolve the phthallic anhydride in acetone, Impregnate the waste with this solution, drive off the solvent, and cure the mixture before molding. Two such runs were made, one using no accelerator and the other using sodium benzene sulfonate. Before molding, the excess phthallic anhydride was extracted with acetone. Fach of the mixtures molded into a pellet, but the latter one using sodiun benzene sulfonate as an accelerator was definitely superior in hardness and homoteneity. Finally, mixtures of phthallic anhydride and citrus waste were ground in a ball mill, with anhydrous $\mathrm{AlCl}_{3}$ and sodium benzene sulfonate as accelerators. These mixtures were cured for 24 hours at $175^{\circ} \mathrm{F}$ and molded. Both produced very atisfactory pellets. After the mixture conteinine $\mathrm{AlCl}_{3}$ was. extrected with acetone to remove unreacted anhydride, it would st1ll mold, but the pellet was very weak.

The compositions and characteristics of the three preceding groups of pellets are condensed in Table VII.

Two additional rung were made using sugar and mannitol in place of citrus waste or cellulose in order to study the general characterlaticB of tho rouction. Equal weights of mannitol, or sugar, and phthallic anhydride were mixed dry and cured at $176^{\circ} \mathrm{F}$ for 16 hours. These powders were molded. The mixture of mannitol and phthallic anhydride produced a small quantity of resinous material during curing. The pellets molded, but were brittle and heterogeneous. 
CONCLUSIONS 
Certain useful interpretations can be made from the experiments performed. Approximately $40 \%$ of the cellulose is taking part In a reaction, even in the formulas where no chemical treatment was used. This is evident from the extraction experiments and 18 confirmed by the mere fact that the proauct will mold. Straight citrus waste, when similarly treated, will not mold. The resin forming characteristica are not due to the melting and recrystallizing of the phthallic anhydride, for the powders could be molded even after extraction with acetone to remove unreacted anhydride.

The use of an accelerating agent is important. Runs 7 and 10 are identiogl in composition but for the use of sodium benzene sulfonate in the latter, and their treatments were very similar, yet loun 10 is definitely superior in hardness and homogeneity.

Intimate contact between the waste and phthallic anhydride is essential. This may be accomplished in two ways - elther by impreenetion with a solution of the anhydride, or by erinding the two components together in a ball mill. Separate grinding and mixing is unsatisfactory. It has been established that citrus waste w1ll react directly with phthallic anhydride without the use of elaborate chemical preparation. An accelerating agent is necessary. The product is moldable. Because of the simplification of the reaction, the material shows comruersial promise. 
LITTRATURE CITED 
(1) Levey, J. Inō. Tre. Chera., 12, 743, 3.920.

(2) Warsh; Food, Introduction to the Chemistry of Cellulose, 829-34, D. van Nostrend Co., 1939.

(3) Worden, Technolow of Celluloge Ttrers:

Vol. 3, p. 1726, Newark Pres8, 1933.

(4) Ibid, Vol. 3, 1735. 
$\mathbf{V}$ I $\mathbf{T} \quad \mathbf{A}$ 
Seaton Long Hunter was born in Louisville, Kentucky, on January 30, 1920, the son of Joseph Aubrey Hunter and Edith Ratcliff Hunter. He recelved his primery school education in the public schools of that city and completed his high school work at du Pont Manual Training High School in Loulaville. He recelved a Bachelor of Chemical Engineering degree from the University of Loulgvilie in June, 1941, and continued his studies at that school under a fellowship in the Division of Indugtrial Reserach. This fellowship was sponsored by the Louiso111e Drying Machinery Company. He received h1s Master of Chemical Engineering degree in May, 1942. Upon completion of his academic work he was omployed by the Monsanto Chemical Company and assigned initially to their research department at Dayton, Oh1o.

Hr. Hunter is a member of Sigma Tau, national honorary engineering fraternity, and Theta Chl Delta, national honorary chemical fraternity. He was president of theta Tau, a netional engineering fretemity, vice president of the Louisville Student Chapter of the A. I. Ch. E., and secretary of the Speed Sclentific School Student Coune 11 . 